\title{
Flipped Classroom in Human Anatomy Teaching and Learning: Performance Analysis and Perceptions of Health Academics
}

\author{
Camila Maria Bandeira Scheunemann ${ }^{\mathrm{a}}$ \\ Caroline Medeiros Martins de Almeida $\mathbb{B}^{\mathrm{b}}$ \\ Paulo Tadeu Campos Lopes $\mathbb{1}^{\mathrm{a}}$
}

\begin{abstract}
${ }^{a}$ Universidade Luterana do Brasil, Programa de Pós-Graduação em Ensino de Ciências e Matemática, Canoas, RS, Brasil ${ }^{\text {b } U n i v e r s i d a d e ~ d o ~ V a l e ~ d o ~ R i o ~ d o s ~ S i n o s, ~ P r o g r a m a ~ d e ~ P o ́ s-G r a d u a c ̧ a ̃ o ~ e m ~ G e s t a ̃ o ~ E d u c a c i o n a l, ~ P o r t o ~ A l e g r e, ~ R S, ~ B r a s i l ~}$

Received for publication on 14 Jan. 2020. Accepted after review on 4 Mar. 2020. Designed editor: Claudia Lisete Oliveira Groenwald
\end{abstract}

\begin{abstract}
Contemporary pedagogical practices have undergone restructuring and paradigm shifts; in this scenario, hybrid teaching emerged, which has as one of its modalities the flipped classroom. This study, of a mixed and exploratory nature, the objective was to investigate the impact of the flipped classroom on academic performance in human anatomy and the students' perceptions of this methodology in their teaching and learning in this discipline. Participants were human anatomy students from health courses at a private university in the metropolitan region of Porto Alegre/RS. A didactic intervention was carried out through the flipped classroom methodology, including the study of the urinary and reproductive systems, where the previous material was made available through two digital hypertexts and in the classroom, digital albums were built. Data were collected through pre and post-test questionnaires, with open questions or Likert scale and analyzed through response scores and content analysis. Participants demonstrated better post-test performance by providing more insight into related content. As for the perceptions, they highlighted the contribution of the flipped classroom to their learning and emphasized as their main positive points their contribution to learning, understanding and memorization, as well as allowing greater interaction and cooperation among colleagues. The most salient negative points were the lack of teacher exposure and the permanence of doubts.

Keywords: flipped classroom; teaching and learning; human anatomy; hybrid teaching.

\section{Sala de Aula Invertida no Ensino e Aprendizagem de Anatomia Humana: Análise do Desempenho e Percepções de Acadêmicos da Área da Saúde}

\section{RESUMO}

As práticas pedagógicas contemporâneas têm passado por reestruturações e mudanças de paradigmas; neste cenário, emergiu o ensino híbrido, que tem como uma de suas modalidades a sala de aula invertida. Este estudo, de natureza mista e exploratória, teve como objetivo investigar o
\end{abstract}

Corresponding author: Camila Maria Bandeira Scheunemann. E-mail: camila.b91@hotmail.com 
impacto da sala de aula invertida no desempenho acadêmico em anatomia humana e as percepções dos estudantes sobre esta metodologia no seu ensino e aprendizagem nesta disciplina. Os participantes foram acadêmicos de anatomia humana de cursos da área da saúde de uma universidade privada da região metropolitana de Porto Alegre/RS. Foi realizada uma intervenção didática por meio da metodologia da sala de aula invertida, contemplando o estudo dos sistemas urinário e reprodutor, onde o material prévio foi disponibilizado através de dois hipertextos digitais, e na aula presencial foram construídos álbuns digitais. Os dados foram coletados mediante questionários de pré e pós-teste, com questões abertas ou em escala Likert e analisados através dos escores das respostas e da análise de conteúdo. Os participantes demonstraram um melhor desempenho no pósteste, apresentando um conhecimento mais esclarecido sobre o conteúdo relacionado. Quanto às percepções, destacaram a contribuição da sala de aula invertida para sua aprendizagem e ressaltaram como seus principais pontos positivos sua contribuição para a aprendizagem, compreensão e memorização, além de possibilitar maior interação e cooperação entre os colegas. Já os pontos negativos mais destacados foram a falta de exposição docente e a permanência de dúvidas. híbrido.

Palavras-chave: sala de aula invertida; ensino e aprendizagem; anatomia humana; ensino

\section{INTRODUCTION}

Pedagogical practices have undergone transformations over time and, nowadays, they are increasingly focused on restructuring and changing paradigms on various aspects, ranging from the functions performed by teachers and students in the teaching and learning process, regarding materials and contemplated strategies, for example. Inrecentyears with the inclusion of digital technologies, hybrid education has been gaining space on the world stage, impacting from Basic Education to Higher Education; thus, it presents itself as a trend in the educational scope, integrating face-to-face and distance activities, with the support of digital technologies. The growth of hybrid education culminated in different teaching modalities, one of which is the flipped classroom (FC) (Christensen, Horn, \& Staker, 2013; Costa, Schuhmacher, \& Schuhmacher, 2016).

E-learning occurs when part of the activities is carried out entirely at a distance and part are carried out in the classroom (Valente, 2014) through electronic media. FC is an e-learning modality, where the study is carried out online and in advance, while the face-to-face class becomes a space for activities of application of the content, with group work and laboratory activities, for example. It consists of inverting the teaching and learning processes that traditionally take place in the classroom and at home (Valente, 2014; Bergman \& Sams, 2018).

FC has been the focus of study in the most diverse disciplines (Pavanelo \& Lima, 2017; Yang, 2017; Rivero-Guerra, 2018) and at all levels of education. However, it is observed that in human anatomy this research is still incipient, needing further study regarding its implications, both in the performance of academics and in their perceptions regarding its use for teaching and learning. Salbego, Oliveira, Silva and Bugança (2015, p. 24) emphasize that "the teaching of human anatomy does not yet show significant changes, even in the midst of technological advances and the evolution of teaching methods". 
Given this context, this article has as its central question: what is the impact of the flipped classroom on academic performance in human anatomy and what are the students' perceptions about this methodology in the teaching and learning process in this discipline? This study aimed to investigate and analyze the impact of the flipped classroom on academic performance in human anatomy and what are the students' perceptions about this methodology in the teaching and learning process in this discipline.

\section{THEORETICAL REFERENCE}

\section{Theoretical assumptions of the flipped classroom}

The central idea of FC is to promote a student interaction before the classroom with an introductory material related to the content, so that this activity replaces the expository instruction carried out in the classroom; with that, classroom time needs restructuring and can be used in a more strategic way, through differentiated activities that allow students to apply and analyze the content, with the classroom and teacher support (Bergman \& Sams, 2014; Bergman, 2018).

With this change in the use of time, especially in person, it can be better used to favor aspects such as the application of concepts and the performance of tasks. FC goes beyond a reorganization of activities over time, as it requires rethinking the entire program of studies (Sánchéz-Rodrigues, Palmero, \& Veja, 2017).

Some important characteristics of FC are: (i) the use of time, due to its restructuring; (ii) the responsibility of the teacher and the student for the deadlines, the teacher in the provision of previous materials and the students in carrying out these activities; (iii) the materials needed for the previous and face-to-face study, which can be varied and prepared by the teachers (Sánchez-Rodrigues, Palmero, \& Veja, 2017; Bergman \& Sams, 2018).

Also, worth mentioning is the role of digital technologies in FC, as they contribute to the availability of previous materials and to the development of activities in the classroom. Another essential aspect refers to the role of teachers and students, since their roles change, the teacher going from transmitter to guide and mediator, and students from passive subjects, to active and protagonists, taking part of the responsibility for their learnings (Valente, 2014; Pavanelo \& Lima, 2017; Sánchéz-Rodrigues, Palmero, \& Veja, 2017).

All these characteristics attributed to FC make it a methodology that has multiple potentials as a pedagogical practice, especially regarding the change of focus from the teacher to the student and the strategic use of classroom time.

\section{Review of empirical studies}

FC had its pioneering studies in countries in North America and Europe; however, far from having a consensus on the subject, there are challenges and conflicting points to be 
investigated and clarified, which makes the topic potential in terms of research, especially in countries in which this methodology is still inserted and may present variations results, due to the different application contexts.

The return on how much research has advanced on FC is relevant, both regarding the performance of students, as well as their perceptions in relation to the methodology. Performance studies and student perceptions provide a body of evidence to discuss classroom inversion (Valente, 2014).

Sommer and Ritzhaupt (2018) applied a survey to examine the impact of the flipped classroom on student performance and satisfaction, in an introductory course on technological literacy, offered at the University of Florida. As a result, they highlight that there were no statistically significant differences between the control and experimental groups regarding performance, with little impact from the methodology, in addition to the students being dissatisfied with the inversion; for the authors, this result is valuable, as it shows that it may not be appropriate for all courses, due to the diversification of the content's cognitive load.

Yang (2017) presents a similar result in his research when he concludes that FC is not suitable for all disciplines; his study aimed to investigate its use in English, in secondary rooms in Hong Kong, regarding the perceptions of students and teachers.

González-Gómez, Cañada, Picó and Jeong (2017) carried out a study at the University Extremadura, in Spain, during the years 2016 and 2017, with the intention of evaluating the impact of FC in the learning of scientific contents, regarding the influence of this model compared to traditional. They perceived, by the responses of the experimental group, the construction of greater meaning for the contents than those of the control group, as well as, higher scores, better preparation and motivation to develop the face-to-face activities.

Martín and Tourón (2017) investigated the students' perceptions in the application of a didactic strategy in FC, in a subject of 'Educational Orientation and tutorial action plan', at the University of Madrid, in the period from 2015 to 2016, with control groups and experimental. The results were favorable to the experimental approach and, according to the students, it favored the development of learning skills, highlighting points such as the different supports and accessibility to the material, being able to follow the pace of study, developing creativity and autonomy, sharing and collaborate with colleagues and practice previously learned theoretical concepts in class.

In the study by Alamri (2019), academic performance and level of satisfaction about FC in Saudi Arabia were researched, using a mixed approach, used to compare traditional and flipped methodologies and in the flipped class, online materials were used and peer instruction. The results indicated a statistically significant difference in student performance and a high degree of satisfaction for the experimental methodology. 
In the literature, incipient information on this theme is also found, especially in Higher Education, with few studies related to its influence and application in science teaching and learning (González-Gómez, Cañada, Picó \& Jeong 2017).

\section{METHODOLOGY}

\section{Study characterization and participants}

The research is characterized as a mixed approach with convergent design, through which an integration between quantitative and qualitative data is sought, in order to arrive at more robust conclusions; despite being marked as "opposites" historically, qualitative and quantitative methods have been integrated in contemporary times for data collection and analysis (Dal-Farra \& Lopes, 2013; Dal-Farra \& Fetters, 2017). Still, this research is exploratory in nature, as it seeks proximity to a problem, improving ideas and intuitions, considering the most varied aspects of the studied fact (Gil, 2007).

This article is part of an ongoing doctoral research, approved by the Ethics Committee of the linked university, under number CAEE 00134418.0.0000.5349, which began in 2018 and presents the data obtained in the realization of its pilot. The participants were a class composed of 18 students, from the discipline of human anatomy of courses in the health area of a private university in the metropolitan region of Porto Alegre/RS.

\section{Pedagogical intervention through flipped class}

A pedagogical intervention was carried out using the FC methodology in the second semester of 2018. For this, the class was divided into two moments, the pre-class and the face-to-face class. For the pre-class, two digital hypertexts were created, one on the Wix Platform and the other on the Google Sites Platform, referring to the urinary and genital systems, themes that would be addressed in the classroom.

The hypertexts were made available to the class a week in advance of the faceto-face class, through a secret group on Facebook and the students would have to carry out their study until the day of that face-to-face class. Figure 1 shows screenshots that exemplify the design of the elaborated materials: 


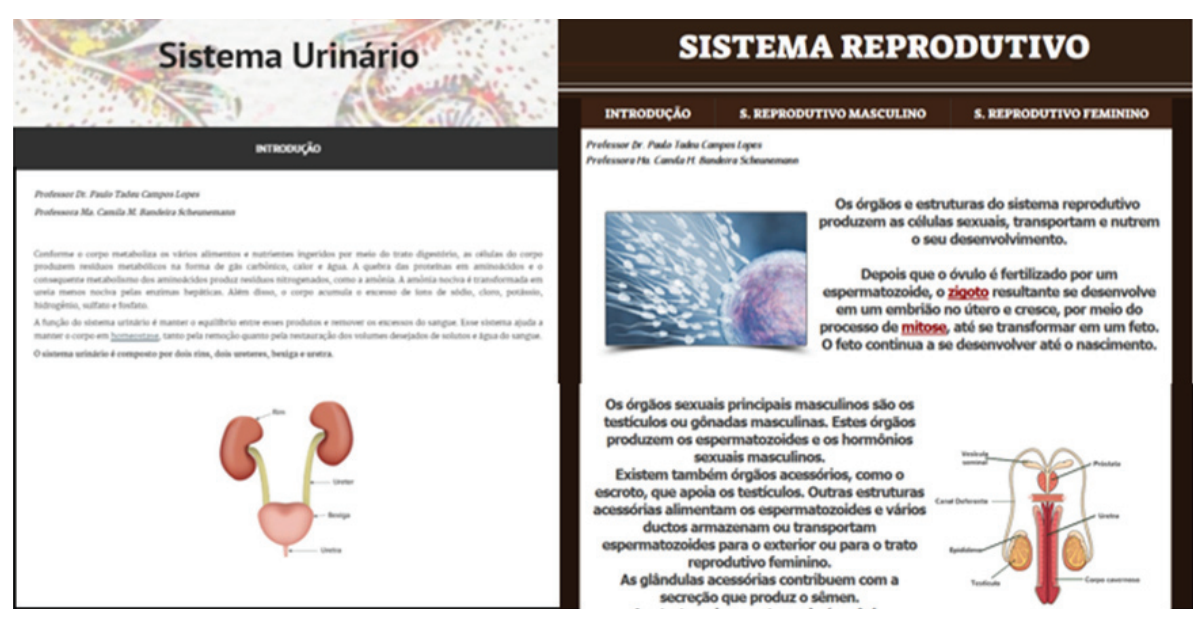

Figure 1. Screenshots that exemplify the elaborated digital hypertexts: on the left on the Google Sites Platform and on the right on the Wix Platform.

The hypertext elaborated on the Google Sites Platform consisted of a page, which presented the description of the structures of the urinary system and their functions; the hypertext elaborated on the Wix Platform consisted of three pages: an introductory one, one for the male reproductive system and another for the female reproductive system. Both had texts, links, images and videos about the referred systems.

In the second moment of the flipped class (face-to-face class) the students applied what they learned in the pre-class through an activity called "Construction of digital album", in which they needed to study the synthetic and moist anatomical pieces available in the human anatomy laboratory to the urinary and reproductive systems, photograph them and create a digital album. Each group built a photo album, and for each of them it should have caption, name of the structure, location of the structure and a short explanatory paragraph about it. Subsequently, the albums were posted to the secret Facebook group, so that the whole class had access. Examples of photos that made up the elaborated albums are shown in Figure 2: 


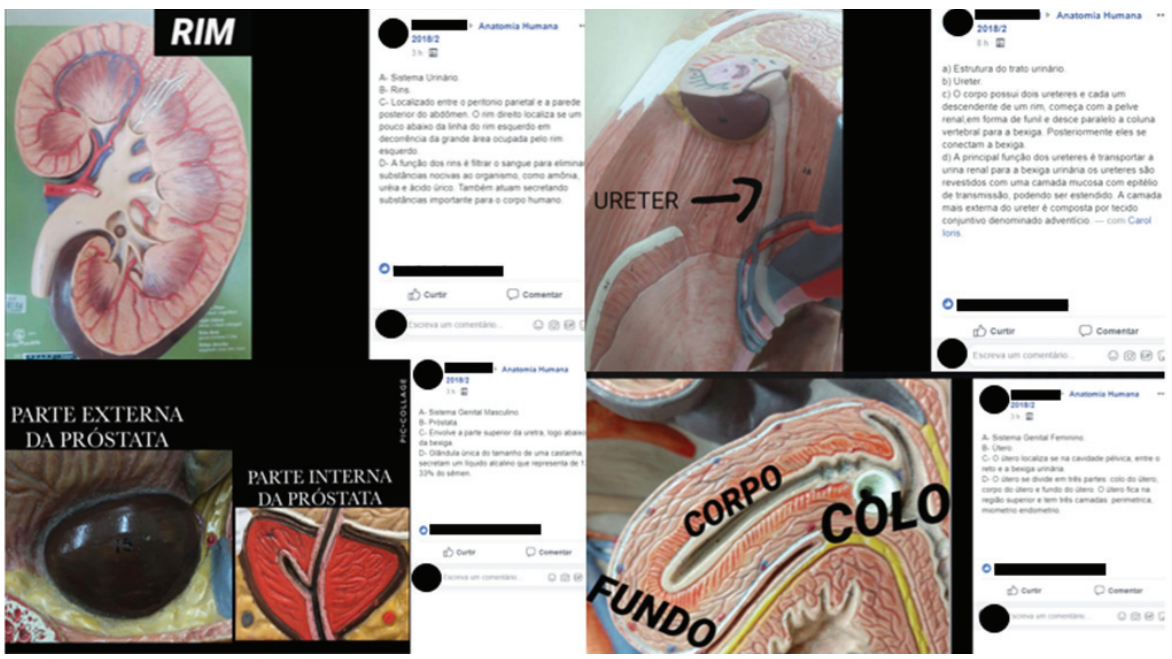

Figure 2. Screenshots that exemplify photos from digital albums produced by academics and posted to the class's secret group on Facebook.

\section{Data collection and analysis}

To collect the data two questionnaires were applied: pre-test and post-test. The pre-test was applied in the class prior to the flipped class, before making digital materials available for the previous study, containing questions related only to the content. The post-test was applied in the class after the flipped class and contained the same questions as the pre-test. In addition, in the post-test, there were questions to verify the students' perceptions about the flipped class held.

The questionnaire questions were open or on a Likert scale; in some, academics needed to mark on the scale and then justify their markings, which contributed to the integrated analysis of the data. Quantitative data were analyzed using descriptive statistics, that is, the scores of students' responses; the qualitative one being defined with respect to its analysis. Qualitative data were analyzed based on Content Analysis, which includes procedures to describe the essence of messages and make inferences about them (BARDIN, 2011). For the content analysis, the corpus considered was the participants' questions and answers; the categorization occurred in a posteriori way (established after the analysis).

\section{RESULTS AND DISCUSSION}

Regarding the profile of the participating students, they represented different courses in the health field, such as Aesthetics and Cosmetics (12); Pharmacy (2); Biomedicine (2), Physiotherapy (1) and Phonoaudiology (1), featuring a very heterogeneous group. 
As for the semester, the class was made up of students from the beginning of the course, with eight from the first semester, nine from the second and one from the third.

The analyzed data were presented in two sessions, one referring to the performance of academics in the pre and post-test and the other about their perceptions in relation to the teaching strategy carried out (FC). For open questions or those that required justification, tables were organized with the categorization of responses, one for each question.

\section{Comparison of academic performance in the pre and post-test}

About the students' performance, data related to questions related to the urinary system and later to the reproductive system, were applied in the pre and post-test.

In the first question the students were asked: "What is the main organ of the urinary system?" The categorization of the pre and post-test can be seen in Table 1:

Table 1

Main organ of the urinary system

\begin{tabular}{ccccc}
\hline Category & Primary subcategories & (f) & Answers (\%) & Students (\%) \\
\hline & Pre-test & & & 44,6 \\
& Bladder & 8 & 44,6 & 38,9 \\
Main organ of the urinary & Kidneys & 7 & 38,9 & 5,5 \\
system & Urethra & 1 & 5,5 & 5,5 \\
& Kidneys, bladder and ureter & 1 & 5,5 & 5,5 \\
\hline Total & No reply & 1 & 5,5 & - \\
\hline \multirow{2}{*}{$\begin{array}{c}\text { Main organ of the urinary } \\
\text { system }\end{array}$} & Post-test & 18 & 100 & $77,8 \%$ \\
& Kidneys & 14 & $77,8 \%$ & 16,7 \\
\hline Total & Bladder & 3 & 16,7 & 5,5 \\
\hline
\end{tabular}

In the pre-test, students expressed a diversity of responses, most frequently for "Bladder" ( $\mathrm{f}=8$ ), which demonstrates a mistaken understanding, since the main organ of the urinary system is the kidneys, which obtained second highest frequency $(\mathrm{f}=7)$. Rodrigues, Meyer, Albuquerque, Oliveira and Souza (2009) in their study found that $60 \%$ of the investigated students related the urinary system, primarily, to the bladder. Although important, the bladder is responsible for the temporary storage of urine, while the kidneys have the primary function of producing it (Bartels et al., 2018; Vieira, Bartels, Calixto \& Passos, 2018). 
Analyzing the post-test responses, it can be seen that the students' understanding changed, as the kidneys showed an increase in frequency $(\mathrm{f}=14)$ and the bladder, a decrease $(\mathrm{f}=3)$. Although some students still pointed to the bladder as the main structure, this number was reduced in relation to the pre-test; in addition, other structures of the urinary system, such as the ureter and urethra, mentioned in the pre-test, were not present in the post-test.

In the study carried out by Wong (2014) it was found that the flipped classroom helped the Pharmacy students in the study of cardiac arrhythmias, which showed an improvement in performance in two of the three classes in which the methodology was applied.

The second question: "Mention all the structures that make up the urinary system", has its categorization shown in Table 2, for the pre and post-test:

Table 2

Structures that make up the urinary system

\begin{tabular}{|c|c|c|c|c|}
\hline Category & Primary subcategories & (f) & Answers (\%) & Students (\%) \\
\hline \multicolumn{5}{|c|}{ Pre-test } \\
\hline \multirow{14}{*}{$\begin{array}{l}\text { Structures that make up } \\
\text { the urinary system }\end{array}$} & Bladder & 17 & 27,5 & 94,4 \\
\hline & Kidneys & 15 & 24,2 & 83,3 \\
\hline & Urethra & 11 & 17,8 & 61,1 \\
\hline & Ovary & 4 & 6,5 & 16,6 \\
\hline & Ureter & 3 & 4,9 & 16,6 \\
\hline & Genitals & 2 & 3,2 & 11,1 \\
\hline & Filtration & 2 & 3,2 & 11,1 \\
\hline & Nephron & 2 & 3,2 & 11,1 \\
\hline & Testicle & 1 & 1,6 & 5,5 \\
\hline & Uterus & 1 & 1,6 & 5,5 \\
\hline & Uterine tubes & 1 & 1,6 & 5,5 \\
\hline & Vagina & 1 & 1,6 & 5,5 \\
\hline & Urinary canal & 1 & 1,6 & 5,5 \\
\hline & No reply & 1 & 1,6 & 5,5 \\
\hline \multirow[t]{2}{*}{ Total } & & 62 & 100 & - \\
\hline & \multicolumn{3}{|c|}{ Post-test } & \\
\hline \multirow{7}{*}{$\begin{array}{l}\text { Structures that make up } \\
\text { the urinary system }\end{array}$} & Kidneys & 18 & 24,7 & 100 \\
\hline & Bladder & 18 & 24,7 & 100 \\
\hline & Urethra & 16 & 21,9 & 88,8 \\
\hline & Ureter & 15 & 20,6 & 83,3 \\
\hline & Nephron & 2 & 2,7 & 11,1 \\
\hline & Genitals & 2 & 2,7 & 11,1 \\
\hline & Prostate & 2 & 2,7 & 11,1 \\
\hline Total & & 73 & 100 & - \\
\hline
\end{tabular}


Based on Table 2, it appears that the students demonstrated to confuse the anatomical structures of the urinary system with those of the reproductive system in the pre-test, as, for example, in the primary subcategories "Ovary", Genitals "," Testis ", among others. The structures of the urinary system most frequently were "Bladder" ( $\mathrm{f}=17$ ), "Kidneys" $(\mathrm{f}=15)$ and "Urethra" $(\mathrm{f}=11)$. Human anatomy students constantly find it difficult to differentiate anatomical structures, as in this discipline there is a large repertoire of contents, which require memorization and associations (Foureaux, Sá, Schetino, Guerra, \& Silva, 2018).

In the post-test, academics deepened their understanding of the anatomical structures of the urinary system, as it significantly decreased the references to the reproductive system, compared to the pre-test. The structures "Kidneys" and "Bladder" were mentioned by all students ( $\mathrm{f}=18$ ) while "Uretra" and "Ureter" also showed an expressive frequency (16 and 15, respectively). Ureter and urethra are structures responsible for transporting urine from the kidneys to the bladder and from this to the outside of the body, respectively (Pereira, Pozzobon, \& Oliveira, 2012).

González-Gómez, Cañada, Picó and Jeong (2017) carried out a research involving an experimental and control group, applying the FC methodology in the first, contemplating the content "Matter and Energy" and observed better learning results in the experimental group, in addition to more illustrative and less memoristic responses when compared to the control group.

The students were asked about the anatomical structures of the reproductive system, answering the question: "Indicate the constituents of the female and male reproductive system". The data regarding the structures of the female reproductive system are categorized in Table 3:

Table 3

Structures of the female reproductive system

\begin{tabular}{ccccc}
\hline Category & Primary subcategories & (f) & Answers (\%) & Students (\%) \\
\hline & Pre-test & & & \\
\hline & Ovaries & 16 & 31,5 & 88,8 \\
& Uterus & 13 & 25,6 & 72,2 \\
Structures of the female & Vagina & 8 & 15,7 & 44,4 \\
reproductive system & Uterine tubes & 5 & 9,9 & 27,7 \\
& Ova/oocytes & 4 & 7,8 & 22,2 \\
& Vulva & 1 & 1,9 & 5,5 \\
& Clitoris & 1 & 1,9 & 5,5 \\
& Urethra & 1 & 1,9 & 5,5 \\
& Genital & 1 & 1,9 & 5,5 \\
\hline \multirow{2}{*}{ Total } & Do not know & 1 & 1,9 & - \\
\hline
\end{tabular}




\begin{tabular}{ccccc}
\hline & \multicolumn{2}{c}{ Post-test } & & \\
\hline & Ovaries & 17 & 25,4 & 94,4 \\
& Uterus & 17 & 25,4 & 94,4 \\
Structures of the female & Vagina & 16 & 23,9 & 88,8 \\
reproductive system & Uterine tubes & 13 & 19,4 & 72,2 \\
& Genitalia & 2 & 2,9 & 11,1 \\
& Oocytes & 1 & 1,5 & 5,5 \\
\hline Total & Ureters & 1 & 1,5 & 5,5 \\
\hline
\end{tabular}

The participants demonstrated to know the structures of the female reproductive system and the most frequent in the pre-test were "Ovaries" $(\mathrm{f}=16)$ and "Uterus" $(\mathrm{f}=13)$; in the post-test the same structures remained but with an increase in frequency especially for "Vagina" ( $\mathrm{f}=16)$ and "Uterine tubes" $(\mathrm{f}=13)$. The data regarding the structures of the male reproductive system are presented in Table 4:

Structures of the male reproductive system

\begin{tabular}{ccccc}
\hline Category & Primary subcategories & (f) & Answers (\%) & Students (\%) \\
\hline & Pre-test & & & \\
& Testicle & 15 & 34,8 & 83,3 \\
& Penis & 13 & 30,2 & 72,2 \\
Structures of the male & Prostate & 6 & 13,9 & 33,3 \\
reproductive system & Sperm & 4 & 9,3 & 22,2 \\
& Scrotal sac & 2 & 4,6 & 11,1 \\
& Urethra & 1 & 2,4 & 5,5 \\
Total & Genital & 1 & 2,4 & 5,5 \\
& Do not know & 1 & 2,4 & - \\
& & 43 & 100 & 9,5 \\
& Pós-teste & & & $-3,4$ \\
& Penis & 17 & 30,3 & 88,8 \\
Structures of the male & Testicle & 16 & 28,5 & 61,1 \\
reproductive system & Prostate & 11 & 19,6 & 38,8 \\
& Scrotal sac & 7 & 12,6 & 11,1
\end{tabular}


The most frequent structures for the male reproductive system in the pre-test were "Testis" ( $\mathrm{f}=15$ ) and "Penis" ( $\mathrm{f}=13)$. It is noted, however, that some structures, such as the attached glands (prostate, seminal vesicles and bulbourethral glands) were rarely mentioned. In the post-test, there was a small increase in frequency, the most expressive for the structures "Prostate" ( $f=11)$ and "Scrotal sac" $(f=7)$.

In the pre and post-test, the students' visual perceptions were also analyzed using images, where they needed to attribute a relationship between them and the referred systems (urinary and reproductive), based on a Likert scale, as shown in Tables 5 and 6. Pinto (2000, p. 42) discusses the use of images in teaching and learning and highlights that they are "a technique that allows the temporal permanence of the registration of something".

Table 5 presents the images to which the students needed to attribute a greater or lesser relationship with the urinary system:

Table 5

Attribution of relationship of images with the urinary system, pre and post-test

\begin{tabular}{|c|c|c|c|c|c|c|c|c|c|c|}
\hline \multirow{2}{*}{ Image } & \multicolumn{2}{|c|}{$\begin{array}{c}\text { Without } \\
\text { Relationship (1) }\end{array}$} & \multicolumn{2}{|c|}{$\begin{array}{c}\text { Little } \\
\text { Related (2) }\end{array}$} & \multicolumn{2}{|c|}{$\begin{array}{l}\text { Moderately } \\
\text { Related (3) }\end{array}$} & \multicolumn{2}{|c|}{ Related (4) } & \multicolumn{2}{|c|}{$\begin{array}{c}\text { Much } \\
\text { Related (5) }\end{array}$} \\
\hline & Pre & Post & Pre & Pos & Pre & Post & Pre & Post & Pre & Post \\
\hline a) & 4 & 11 & 0 & 3 & 5 & 2 & 4 & 1 & 5 & 1 \\
\hline & $22,2 \%$ & $61,1 \%$ & - & $16,6 \%$ & $27,7 \%$ & $11,1 \%$ & $22,2 \%$ & $5,5 \%$ & $27,7 \%$ & $5,5 \%$ \\
\hline b) & 1 & - & 1 & - & 3 & - & 2 & 2 & 11 & 16 \\
\hline & $5,5 \%$ & - & $5,5 \%$ & - & $16,6 \%$ & - & $11,1 \%$ & $11,1 \%$ & $61,1 \%$ & $88,8 \%$ \\
\hline c) & 2 & 1 & 3 & - & 6 & - & 2 & - & 5 & 17 \\
\hline & $11,1 \%$ & $5,5 \%$ & $16,6 \%$ & - & $33,3 \%$ & - & $11,1 \%$ & - & $27,7 \%$ & $94,4 \%$ \\
\hline d) & 6 & 6 & 4 & 5 & 4 & 2 & 3 & 2 & 1 & 3 \\
\hline & $33,3 \%$ & $33,3 \%$ & $22,2 \%$ & $27,2 \%$ & $22,2 \%$ & $11,1 \%$ & $16,6 \%$ & $11,1 \%$ & $5,5 \%$ & $16,6 \%$ \\
\hline
\end{tabular}


The images presented in Table 5 refer to the following anatomical structures: female reproductive system (a); urinary system (b); cut kidney (c) and pancreas (d). Therefore, the ones most related to the urinary system were those represented by the letters $\mathbf{b}$ and $\mathbf{c}$, which showed a percentage increase, in the image b from $61.1 \%$ in the pre-test to $88.8 \%$ in the post-test (as very related); and in the image $\mathbf{c}$ from $27.7 \%$ in the pre-test to $94.4 \%$ in the post-test (for very related). This points out that the study of the urinary system in an inverted way, with regard to visual perception, helped the participants, mainly, in the visual identification of the anatomical structure of a kidney (image c), by the expressive increase in the percentage of relationship.

There was also a decrease in the percentage of image a as unrelated to the urinary system, from $22.2 \%$ in the pre-test to $61.1 \%$ in the post-test, indicating a better visual understanding of the difference between the urinary and reproductive systems, corroborating the results presented in Table 2 regarding the post-test, where the participants showed less confusion between the structures of these two systems.

Table 6 presents the analysis of the images to which the students needed to attribute a greater or lesser relationship with the reproductive system:

Table 6

Attribution of relationship of images with the reproductive system, pre and post-test

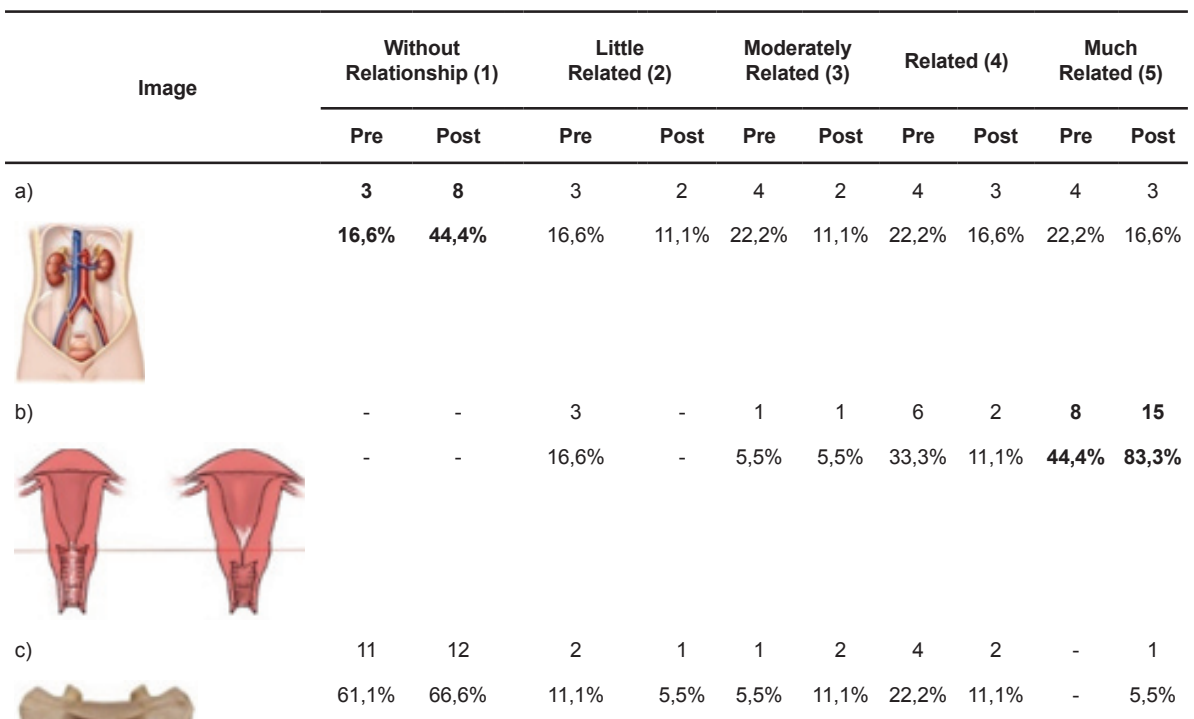




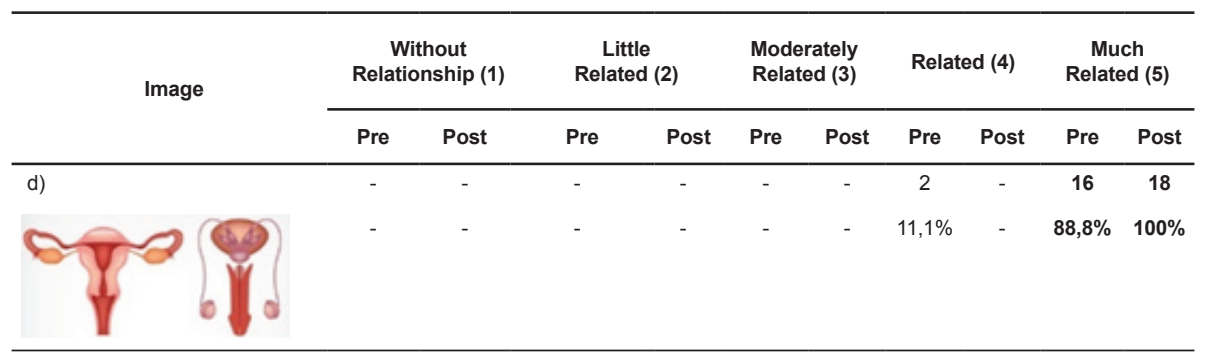

The images shown in Table 6 refer to the following anatomical structures: urinary system (a); female reproductive system (partial representation) (b); sacrum bone (c) and male and female reproductive systems (d). Therefore, the images most related to the reproductive system were those represented by the letters bed, for which the relationship growth was also observed, with a percentage increase, in image b from $44.8 \%$ in the pretest to $83.3 \%$ in the post-test (as very related) and in the image $\mathbf{d}$ from $88.8 \%$ to $100 \%$ (very related), showing a high percentage of agreement.

In the same way as in Table 5, in Table 6 there was a decrease in the ratio in image a (from $16.6 \%$ to $44.8 \%$, for 'no relationship'), corroborating the fact that students improved their differentiation visual of the structures of the urinary and reproductive systems, which often confuse.

Neves (2010) researched the use of images and drawings in the teaching and learning of human anatomy and pointed out that $98 \%$ of the investigated students believe in its help as an element of study in the meaning of anatomical contents. Therefore, it is not enough to learn the name of anatomical structures, it is essential that students in the field of health know how to recognize them visually.

\section{Perceptions of academics about the methodology of the Flipped Classroom}

In addition to comparing pre and post-test data regarding student performance we sought to analyze their perceptions about the flipped classroom. Analyzing students' perceptions of a pedagogical practice is quite valid, as it helps to clarify the positive and negative points of the intervention performed.

The students were asked about the contribution of the flipped class to their learning of human anatomy, the result of which is expressed in Figure 3: 


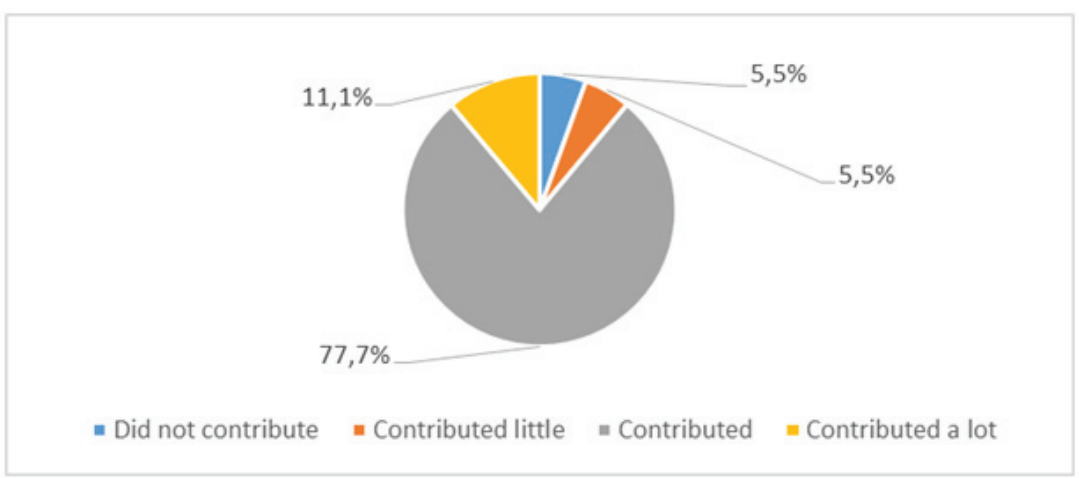

Figure 3. Contribution of the flipped class to the learning of human anatomy.

The data in Figure 3 show that, for most students, the flipped class contributed $(77.7 \%)$ or contributes a lot $(11.1 \%)$ to their learning. The "Indifferent" alternative was not represented on the Likert scale; therefore, it is not expressed in Figure 3. A similar result was found by Rivero-Guerra (2018) with students of Biological and Pharmaceutical Sciences in the discipline of Botany, in Colombia, where academics presented favorable perceptions about the flipped methodology.

To better understand the students' position on this question, they were asked to justify their answers, which are categorized in Table 7:

Table 7

FC's contribution to the learning of human anatomy, justifications

\begin{tabular}{|c|c|c|c|c|c|}
\hline Category & $\begin{array}{c}\text { Primary } \\
\text { subcategories }\end{array}$ & Secundary subcategories & (f) & $\begin{array}{l}\text { Answers } \\
(\%)\end{array}$ & $\begin{array}{l}\text { Students } \\
(\%)\end{array}$ \\
\hline \multirow{13}{*}{$\begin{array}{l}\text { Contribution of FC } \\
\text { in the learning of } \\
\text { human anatomy }\end{array}$} & \multirow[t]{9}{*}{ Contributed } & Facilitates learning & 4 & 22,4 & 22,4 \\
\hline & & Different way of learning & 2 & 11,3 & 11,3 \\
\hline & & Help with memorization & 2 & 11,3 & 11,3 \\
\hline & & Aroused interest & 1 & 5,5 & 5,5 \\
\hline & & $\begin{array}{c}\text { Requires more effort and } \\
\text { dedication }\end{array}$ & 1 & 5,5 & 5,5 \\
\hline & & Exchange between groups & 1 & 5,5 & 5,5 \\
\hline & & Encouraged research & 1 & 5,5 & 5,5 \\
\hline & & Creativity & 1 & 5,5 & 5,5 \\
\hline & & Without justification & 1 & 5,5 & 5,5 \\
\hline & \multirow{2}{*}{$\begin{array}{c}\text { Contributed } \\
\text { a lot }\end{array}$} & Efficient method & 1 & 5,5 & 5,5 \\
\hline & & Without justification & 1 & 5,5 & 5,5 \\
\hline & $\begin{array}{l}\text { Contributed } \\
\text { little }\end{array}$ & $\begin{array}{l}\text { It didn't add much } \\
\text { knowledge }\end{array}$ & 1 & 5,5 & 5,5 \\
\hline & $\begin{array}{l}\text { Did not } \\
\text { contribute }\end{array}$ & $\begin{array}{l}\text { Because the teacher spends } \\
\text { little content }\end{array}$ & 1 & 5,5 & 5,5 \\
\hline Total & & & 18 & 100 & - \\
\hline
\end{tabular}


For students who answered "Contributed" (77.7\%), the main justification was that the methodology "Facilitates learning" ( $\mathrm{f}=4)$, which is a "Different way of learning" $(\mathrm{f}=2)$ and that "Help with memorization" ( $\mathrm{f}=2)$.

It is worth highlighting the justification of the student who considers that the methodology "Did not contribute", because for him the teacher "Passes little content", which expresses a conception still present in teaching, that the important thing is the amount of content that the teacher gets to transmit. Sánchez-Rodríguez, Palmero and Veja (2017) comment on the differences in the teacher's roles in the methodology considered traditional and in $\mathrm{FC}$; in the first, the teacher is seen as a transmitter; in the second, its task focuses on guiding, assisting, providing more personalized advice, promoting greater participation and interaction.

Academics were asked: "Do you believe that flipped classes in other subjects of your course would be a good methodological option for your learning? Tick and justify". For this question, $88.8 \%$ of the participants answered yes and $11.2 \%$ that they did not; the justifications were categorized in Table 8:

Table 8

Flipped classes in other undergraduate subjects

\begin{tabular}{|c|c|c|c|c|c|}
\hline Category & $\begin{array}{c}\text { Primary } \\
\text { subcategories }\end{array}$ & Secundary subcategories & (f) & Answers (\%) & $\begin{array}{l}\text { Students } \\
(\%)\end{array}$ \\
\hline \multirow{11}{*}{$\begin{array}{l}\text { Flipped classes } \\
\text { in other } \\
\text { undergraduate } \\
\text { subjects }\end{array}$} & \multirow[t]{9}{*}{$\begin{array}{l}\text { It would be a good } \\
\text { methodological option }\end{array}$} & $\begin{array}{l}\text { Leaves the conventional/ varies } \\
\text { the methodology }\end{array}$ & 3 & 16,7 & 16,7 \\
\hline & & Facilitates/improves learning & 3 & 16,7 & 16,7 \\
\hline & & $\begin{array}{l}\text { May be useful in some/all } \\
\text { subjects }\end{array}$ & 2 & 11,2 & 11,2 \\
\hline & & $\begin{array}{l}\text { Provides basis/preparation } \\
\text { for class }\end{array}$ & 2 & 11,2 & 11,2 \\
\hline & & Without justification & 2 & 11,2 & 11,2 \\
\hline & & $\begin{array}{l}\text { It helps to study more } \\
\text { dynamically }\end{array}$ & 1 & 5,5 & 5,5 \\
\hline & & $\begin{array}{l}\text { In disciplines with higher } \\
\text { content demand }\end{array}$ & 1 & 5,5 & 5,5 \\
\hline & & $\begin{array}{l}\text { Although good, there is a need } \\
\text { for printed material }\end{array}$ & 1 & 5,5 & 5,5 \\
\hline & & $\begin{array}{l}\text { Despite believing in the } \\
\text { methodology, prior study } \\
\text { requires time for study }\end{array}$ & 1 & 5,5 & 5,5 \\
\hline & \multirow{2}{*}{$\begin{array}{l}\text { It would not be a good } \\
\text { methodological option }\end{array}$} & In practical classes & 1 & 5,5 & 5,5 \\
\hline & & Without justification & 1 & 5,5 & 5,5 \\
\hline Total & & & 18 & 100 & - \\
\hline
\end{tabular}


The most frequent justifications in favor of flipped classes in other subjects of the course were because "It leaves the conventional/the methodology varies" ( $\mathrm{f}=3)$ and "It facilitates and improves learning" ( $\mathrm{f}=3$ ). Other justifications were for being a useful methodology and providing a basis/preparation for the class. The students' prior contact with the content helps in preparing for the face-to-face meeting, so that, if the pre-class study is effective, it can help in understanding what concepts have not yet been understood and provide support for a better use of the face-to-face meeting, allowing the deepening and application of the content (Valente, 2014).

The participants answered the question: "Previously to this discipline, had you already participated in a flipped class? If so, comment on when and in which discipline". For this question, $77.6 \%$ of the students said that they had never previously participated in a flipped class and $22.2 \%$ that they had already. Table 9 explains the students' other experiences with flipped classes:

Table 9

Participation in flipped classes before the discipline of human anatomy

\begin{tabular}{|c|c|c|c|c|c|}
\hline Category & Primary subcategories & Secundary subcategories & (f) & $\begin{array}{c}\text { Answers } \\
(\%)\end{array}$ & $\begin{array}{c}\text { Students } \\
(\%)\end{array}$ \\
\hline \multirow{5}{*}{$\begin{array}{l}\text { Participation in flipped } \\
\text { classes before the } \\
\text { discipline of human } \\
\text { anatomy }\end{array}$} & No & - & 14 & 77,6 & 77,6 \\
\hline & Yes & English course & 1 & 5,6 & 5,5 \\
\hline & & Oral health assistant course & 1 & 5,6 & 5,5 \\
\hline & & Accounting technical course & 1 & 5,6 & 5,5 \\
\hline & & It wasn't in college & 1 & 5,6 & 5,5 \\
\hline Total & & & 18 & 100 & - \\
\hline
\end{tabular}

Of the four students who said they had participated in an flipped class prior to the discipline, two reported this practice in a technical course and another only specified that it was not in college; based on these specific experiences, there is little use of FC in Higher Education, since the experiences reported were in other teaching environments.

Table 10 shows the categorization for the question: "Indicate the differences that you noticed in relation to the FC methodology, when compared to a traditional class": 
Table 10

Differences between FC and traditional class

\begin{tabular}{|c|c|c|c|c|c|}
\hline Category & $\begin{array}{c}\text { Primary } \\
\text { subcategories }\end{array}$ & Secundary subcategories & (f) & Answers (\%) & Students (\%) \\
\hline \multirow{17}{*}{$\begin{array}{c}\text { Differences } \\
\text { between FC } \\
\text { and traditional } \\
\text { class }\end{array}$} & \multirow[t]{8}{*}{ Positive for FC } & $\begin{array}{l}\text { Greater/better learning, } \\
\text { understanding/memorizing/fixing } \\
\text { the contents }\end{array}$ & 6 & 16,3 & 33,3 \\
\hline & & $\begin{array}{l}\text { Greater interaction/cooperativity/ } \\
\text { exchanges and activities with } \\
\text { colleagues }\end{array}$ & 5 & 13,5 & 27,7 \\
\hline & & $\begin{array}{l}\text { More fun/dynamic/versatile class; } \\
\text { less tiring and boring }\end{array}$ & 3 & 8,1 & 16,6 \\
\hline & & Know what you will learn in advance & 2 & 5,4 & 11,1 \\
\hline & & No reply & 2 & 5,4 & 11,1 \\
\hline & & Putting the study into practice & 1 & 2,7 & 5,5 \\
\hline & & Ask questions & 1 & 2,7 & 5,5 \\
\hline & & Getting more prepared & 1 & 2,7 & 5,5 \\
\hline & \multirow[t]{9}{*}{ Negatives for FC } & Lack of teacher exposure & 3 & 8,1 & 16,6 \\
\hline & & Doubts that remain & 3 & 8,1 & 16,6 \\
\hline & & No reply & 3 & 8,1 & 16,6 \\
\hline & & Too much time involved & 2 & 5,4 & 11,1 \\
\hline & & Lack of time for prior study & 1 & 2,7 & 5,5 \\
\hline & & Short time to perform & 1 & 2,7 & 5,5 \\
\hline & & Reading at home & 1 & 2,7 & 5,5 \\
\hline & & Learning difficulties & 1 & 2,7 & 5,5 \\
\hline & & $\begin{array}{l}\text { Possibility of not studying all the } \\
\text { content }\end{array}$ & 1 & 2,7 & 5,5 \\
\hline Total & & & 37 & 100 & - \\
\hline
\end{tabular}

Table 10 shows the positive points for FC, when compared to the traditional class and the reason for the higher frequency was that it contributes to learning, understanding and memorizing content $(\mathrm{f}=6)$; and that enables greater interaction and cooperation between colleagues $(\mathrm{f}=5)$. FC encourages social and collaborative exchanges between colleagues, which is generally less emphasized in a traditional class. The increase in collaborative work among students can mean greater impact on the development of cognitive processes, reflecting improvements in their assessments, which can be provided by class inversion (Valente, 2014; Rivero-Guerra, 2018).

Lage, Platt and Treglia (2000) highlight other positive features of FC, such as the responsibility of students for their study, assistance with classroom tasks in groups, contemplation of various learning styles, greater openness to questions and possibilities for interaction.

As for the negative points for $\mathrm{FC}$, when compared to the traditional class, the most mentioned were "Lack of teacher exposure" $(\mathrm{f}=3)$ and "Doubts that remain" $(\mathrm{f}=3)$; thus, the aspect 'lecture class' appears again, corroborating data presented in Table 7, when referring to the amount of expository content passed by the teacher, pointed out as one of the main complaints of the students, in Table 10. 
A similar result was found in the research by Pavanelo and Lima (2017), who took an flipped class in Engineering courses at the Technological Institute of São Paulo, in Calculus I classes and evaluated the students' perceptions regarding their anxieties about FC, the lack of expository class being a very mentioned aspect.

The participants were asked about the contribution of the flipped classroom in increasing their interest and motivation in the discipline of human anatomy, whose data are shown in Figure 4:

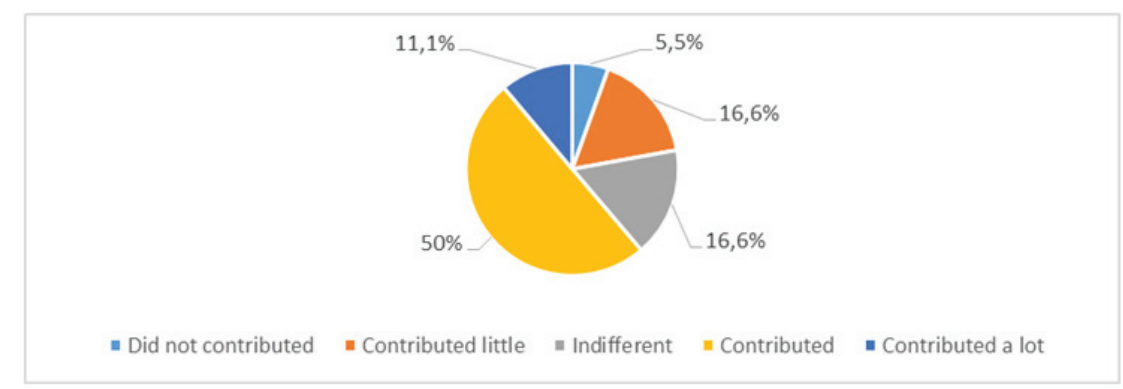

Figure 4. Contribution of the flipped class to increase interest and motivation in human anatomy

Figure 4 indicates that $61.1 \%$ of the participants consider that FC contributed or contributed a lot to increase their interest and motivation in human anatomy. Motivation is a relevant factor in this methodology, as its lack can be unfavorable; less motivated students can achieve inappropriate results, since the rates of learning in FC depend on self-motivation (Yang, 2017; Sánchez-Rodríguez, Palmero, \& Veja 2017).

For this question, students also needed to justify their answers, which are presented in Table 11: 
Contribution of the flipped classroom to the interest and motivation in human anatomy, justifications

\begin{tabular}{|c|c|c|c|c|c|}
\hline Category & $\begin{array}{c}\text { Primary } \\
\text { subcategories }\end{array}$ & Secundary subcategories & (f) & Answers (\%) & Students (\%) \\
\hline \multirow{17}{*}{$\begin{array}{l}\text { FC's contribution } \\
\text { to interest and } \\
\text { motivation in human } \\
\text { anatomy }\end{array}$} & \multirow[t]{8}{*}{ Contributed } & Easier to understand & 1 & 5,2 & 5,2 \\
\hline & & Different dynamics & 1 & 5,2 & 5,2 \\
\hline & & More fun to study this way & 1 & 5,2 & 5,2 \\
\hline & & $\begin{array}{l}\text { Helps contribute to the learning of } \\
\text { colleagues }\end{array}$ & 1 & 5,2 & 5,2 \\
\hline & & $\begin{array}{l}\text { Different methods increase interest } \\
\text { in the discipline }\end{array}$ & 1 & 5,2 & 5,2 \\
\hline & & $\begin{array}{l}\text { Research was needed, which } \\
\text { increased interest }\end{array}$ & 1 & 5,2 & 5,2 \\
\hline & & $\begin{array}{l}\text { It is easier with anatomical pieces } \\
\text { as they help in locating the } \\
\text { structures }\end{array}$ & 1 & 5,2 & 5,2 \\
\hline & & Without justification & 2 & 11,6 & 11,6 \\
\hline & \multirow[t]{3}{*}{ Indifferent } & $\begin{array}{c}\text { The motivation comes from the } \\
\text { student }\end{array}$ & 1 & 5,2 & 5,2 \\
\hline & & There was interest in both methods & 1 & 5,2 & 5,2 \\
\hline & & Without justification & 1 & 5,2 & 5,2 \\
\hline & \multirow[t]{3}{*}{ Contributed little } & I was more motivated & 1 & 5,2 & 5,2 \\
\hline & & $\begin{array}{c}\text { Study before class increases } \\
\text { interest }\end{array}$ & 1 & 5,2 & 5,2 \\
\hline & & $\begin{array}{l}\text { Discipline with a lot of content is } \\
\text { better traditional class }\end{array}$ & 1 & 5,2 & 5,2 \\
\hline & \multirow[t]{2}{*}{ Contributed a lot } & $\begin{array}{c}\text { Makes people more excited, allows } \\
\text { them to dedicate and contribute } \\
\text { in groups }\end{array}$ & 1 & 5,2 & 5,2 \\
\hline & & Without justification & 1 & 5,2 & 5,2 \\
\hline & $\begin{array}{l}\text { Did not } \\
\text { contribute }\end{array}$ & Without justification & 1 & 5,2 & 5,2 \\
\hline Total & & & 18 & 100 & - \\
\hline
\end{tabular}

The categorization of the justifications presented a diversity of positions of the academics, but which were related to the motivation and the interest provided to a greater or lesser degree by the methodology. Some justifications expressed about the methodology contributing to the interest and motivation were: "Easier to understand"; "Different dynamics"; "More fun to study this way".

Other answers that elucidate why this contribution, for example, are: "Different methods increase interest in the discipline"; "It was necessary to research, which increased the interest"; "Study before class increases interest". However, justifications that clarify why some students consider that it does not influence interest and motivation, were: "The motivation comes from the student"; "There was interest in both methods"; "Discipline with a lot of content is better traditional class".

In the research by Viégas, Bacellar and Rehfeldt (2017) the results indicated that the students felt more motivated participating in a flipped class, exposing their ideas and experiences in the face-to-face class and attributed as a positive point that it privileges 
group activities. A study by Wong et al. (2014) with Pharmacy students, through FC showed greater satisfaction in this type of class.

\section{CONCLUSIONS}

This research aimed to investigate the impact of the flipped classroom on academic performance in human anatomy and what are the students'perceptions about this methodology in teaching and learning in this discipline.

Regarding the performance of the participants, comparing the pre-test data with the post-test data, it was observed that the students demonstrated a better knowledge about what are the anatomical structures of the urinary and reproductive systems in the post-test and to which of them each belongs. The analysis of the images corroborated this result, with changes in the scores and expansion of the relationship established between the image and the system, properly.

As for the participants' perceptions about the FC methodology, $88.8 \%$ said that it contributed or contributed a lot to their learning, justifying that it facilitates learning, it is a different way of learning and helping with memorization. Regarding the contribution of the methodology to increase interest and motivation, the data were more heterogeneous, with different opinions, where $50 \%$ of the participants believe that it helped in this aspect.

About the main differences between FC and traditional teaching, academics highlighted their positive contribution to learning, understanding and memorization; in addition, they stressed that it enables greater interaction and cooperation between colleagues. The most prominent negative aspects for FC were the lack of teacher exposure and the remaining doubts. In addition, $77.8 \%$ of the participants had never participated in an flipped class before this experience, which indicates their little insertion in academic environments; despite this, $88.8 \%$ believe that it would be a good methodological option for other subjects in their course, as it goes beyond the conventional and facilitates learning.

Although this investigation has limitations, such as the sample size, which is why new studies of this nature are suggested in other contexts and classes of human anatomy, it contributes by presenting the use of the flipped classroom in this discipline, with regard to the performance of students and their perceptions about this methodology in teaching and learning, a subject that is still little explored in the literature. It also contributes by presenting higher education students' conceptions about the structures of the urinary and reproductive systems, which is evident in a small number of studies.

It is intended, as a continuation of this research, to investigate in isolation some elements of flipped classes, such as previous study, previous study materials and students' involvement in this stage, as well as the interactions and activities carried out in the classroom, in the teaching of human anatomy. 


\section{ACKNOWLEDGMENTS AND SUPPORT}

This work was carried out with the support of the Coordenação de Aperfeiçoamento de Nível Superior (CAPES) - Financing Code 001.

\section{AUTHORS' CONTRIBUTION DECLARATIONS}

This article was prepared and organized by the three authors. C.M.B.S. developed the theoretical framework, the methodology and collected the data. C.M.B.S. and C.M.M.A. analyzed the data and worked on the general construction of the article. P.T.C.L. supervised the project.

\section{DESCRIPTION OF DATA AVAILABILITY}

The authors agree to make the data that support the results of this study available upon reasonable request from a reader and it is up to the authors to determine whether a request is reasonable or not.

\section{REFERENCES}

Alamri, M. M. (2019). Students' academic achievement performance and satisfaction in a flipped classroom in Saudi Arabia. International Journal of Technology Enhanced Learning, 11(1), 103-118.

Bardin, L. (2011). Análise de conteúdo. São Paulo: Edições 70.

Bartels, M. P. B, Vieira, I. D., Calixto, F. R. P., Oliveira, C. H. S., Oliveira, P. H. M., \& Passos, M. A. F. (2018). Anatomia do abdome. In: Soares, L. G. B., Calixto, F. R. P., \& Oliveira, P. H. M. (Org.). Clínica cirúrgica para o generalista. Teresópolis: Editora UNIFESO.

Bergman, J. (2018). Aprendizagem invertida para resolver o problema do dever de casa. Tradução: Henrique de Oliveira Guerra. Porto Alegre: Penso.

Bergman, J., \& Sams, A. (2014). Flipped learning: gateway to student engagement. ISTE: Washington.

Bergman, J., \& Sams, A. (2018). Sala de aula invertida: uma metodologia ativa de aprendizagem. Tradução: Afonso Celso da Cunha Serra. Rio de Janeiro: LTC.

Christensen, C. M., Horn, M. B., \& Staker, H. (2013). Is K-12 Blended Learning Disruptive? An introduction to the theory of hybrids. Clayton Christensen Institute.

Costa, L. M. C. L., Schuhmacher, E., \& Schuhmacher, V. R. N. (2016). Contribuições da aprendizagem significativa na construção de uma proposta de um curso de nivelamento semipresencial de Física Básica. Acta Scientiae, 18(3), 756-770.

Dal-Farra, R. A., \& Fetters, M. D. (2017). Recentes avanços nas pesquisas com métodos mistos: aplicações nas áreas de Educação e Ensino. Acta Scientiae, 19(3), 466-492. 
Dal-Farra, R. A., \& Lopes, P. T. C. (2013). Métodos mistos de pesquisa em educação: pressupostos teóricos. Nuances: estudos sobre Educação, 24(3), 67-80.

Foureaux, G., Sá, M. A., Schetino, L. P. L., Guerra, L. B., \& Silva, J, H. (2018). O ensino-aprendizagem da anatomia humana: avaliação do desempenho dos alunos após a utilização de mapas conceituais como uma estratégia pedagógica. Ciência \& Educação, 24(1), 95-110.

Gil, A. C. (2007). Como elaborar projetos de pesquisa. 4 ed. São Paulo: Atlas.

González-Gómez, D., Cañada, F. C., Picó, A. G., \& Jeong, J. S. (2017). Enseñanza de contenidos cientificos atraves de un modelo $<$ Flipped $>$ : propuesta de instrucción para estudiantes del grado de educación primária. Enseñanza de las Ciências, 35(2), 71-87. Lage, M. J., Platt, G. J., \& Treglia, M. (2000). Inverting the Classroom: A Gateway to Creating an Inclusive Learning Environmental. Journal of Economic Education, 3043.

Martin, D., \& Tourón, J. (2017). El enfoque flipped learning en estúdios de magistério: percepción de los alunos. Revista Iberoamericana de Educación a Distáncia, 20(2), 187-211.

Neves, M. V. S. (2010). Uma nova proposta no ensino de anatomia humana: desafios e novas perspectivas. (56f.). Dissertação de mestrado, Centro Universitário de Volta Redonda, Volta Redonda.

Pavanelo, E., \& Lima, E. (2017). Sala de aula invertida: a análise de uma experiência na disciplina de Cálculo I. Bolema: Boletim de Educação Matemática, 31(58), 739-759.

Pinto, P. G. H. R. (2000). Saber ver: recursos visuais e formação médica. Physis: Revista Saúde Coletiva, 10(1), 39-64.

Pereira, G. A. M., Pozzobon, A., \& Oliveira, V. C. B. D. (2012). Anatomia na prática. Lajeado: Editora Univates.

Rivero-Guerra, A. O. (2018). Practica de Laboratório de Granos de Almidón em um Curso de Botánica General: una experiencia de classe invertida. Formación Universitária, 11(1), 87-104.

Rodrigues, A. S. B., Meyer, M., Albuquerque, E., Oliveira, F. G. V., \& Souza, K. S. (2009). Oficina pedagógica interdisciplinar como ferramenta metodológica no ensino da função renal. In: Anais da Jornada de Pesquisa, Ensino e Extensão-JPEX. (pp. 1-3). Universidade Federal Rural de Pernambuco, Pernambuco, Brasil.

Salbego, C., Oliveira, E. M. D., Silva, M. A. R., \& Bugança, P. R. (2015). Percepções Acadêmicas sobre o Ensino e a Aprendizagem em Anatomia Humana. Revista Brasileira de Educação Médica, 39(1), 23-31.

Sánchez-Rodríguez, J., Palmero, J. R., \& Veja, E. S. (2017). Flipped Classroom. Claves para su puesta em practica. EDMETIC-Revista de Educación Mediática y TIC, 6(2), 336-358.

Sommer, M., \& Ritzhaupt, A. (2018). Impact of the Flipped Classroom on learner achievment and satisfaction in an undergraduate Technology Litracy Course. Journal of Information Technology Education, 17, 159-182.

Valente, J. A. (2014). Blended learning e as mudanças no ensino superior: a proposta da sala de aula invertida. Educar em Revista, Edição Especial, (4), 79-97. 
Viégas, S. R. C., Bacellar, T. M., \& Rehfeld, M. J. H. (2017). Sala de aula invertida como metodologia ativa: percepção dos estudantes do curso de pedagogia em uma faculdade do Maranhão. Revista Tecnologias na Educação, 9(18).

Vieira, I. D., Bartels, M. P. B., Calixto, F. R. P., \& Passos, M. A. F. (2018). Anatomia da Pelve. In: Soares, L. G. B., Calixto, F. R. P., \& Oliveira, P. H. M. (Org.). Clínica cirúrgica para o generalista. Teresópolis: Editora UNIFESO.

Yang, C. C. R. (2017). An investigation of the use of the "Flipped Classroom" pedagogy in secondary english lenguage classrooms. Journal of Information Technology Education, $16,1-20$.

Wong, T. H., Ip, E. J., Lopes, I., \& Rajapopalan, V. (2014). Pharmacy Students' Performance and Perceptions in a Flipped Teaching Pilot on Cardiac Arrhythmias. American Journal of Pharmaceutical Education, 78(10), 1-6. 